\title{
An Analysis of Organisational Role Stress among Employees of IT Companies in Bangalore
}

\author{
R. Rajeswari ${ }^{1 *}$ and G. A. Sudershan ${ }^{2}$ \\ 'Principal, Sri Sarada College for Women (Autonomous), Salem, Tamilnadu, India; raji_2pink@yahoo.com \\ ${ }^{2}$ Acharya First Grade College for Women, Gauribidanur, Karnataka, India
}

\begin{abstract}
Long-term productivity of a company relies on its diligent human resources. But the diligence beyond a limit pressurises the performer. So, strainful careers though lucrative are not without their negative outcomes such as, unpleasant state of mind, physical and emotional imbalance and threat to the well being of the performers. Hence, an analysis has been made in this paper to identify the role stress [1] and the sources/causes of the same among employees working in the IT companies in Bangalore city. The study has divulged the fact that the role stress [1] acquainted by the employees is not identical but diverse, which affirms the findings of Srivastav [1].
\end{abstract}

Keywords: IT Companies, Organisational Role Stress, Role Stress, Stress, Work Stress

\section{Introduction}

Long-term productivity of a company rests on intensely committed human resources. But for the diligent work force, such jobs though lucrative and rewarding are not without their negative outcomes such as, unpleasant state of mind, physical and emotional imbalance and threat to their well being. Hence this paper probes the organizational role stress [1] experienced by the employees of IT companies, as they are known for rendering mentally oriented skilful jobs for longer and extended hours.

\section{Review of Literature}

Srivastav [1] has examined the state and intricacies of role stress and that of the role stressors. Pareek [2] by employing factor analysis has yielded an exhaustive role stress measurement scale with 50 items for the measurement of 10 role stressors known as Organizational Role Stress (ORS) Scale. Terry [3] tried to analyse the work-role stress and the association between the attitude towards co-workers and work-role stress. Ahmed, Bharadwaj and Narula [4] have probed the level of role stress within the male executives of public and private sector organizations. An attempt was made by Pestonjee [5] to examine the kinds of role stresses confronted by managers at top and middle hierarchies. Satyanarayana [6] has perused the stressors amid executive and supervisory cadres of Bharat Heavy Electrical Ltd (BHEL). Ritu Lehal and Sukhdeep Singh [7] have asserted that the role stress of teaching fraternity serving in private institutions were higher when compared to government institutions of higher education. Yasmeen and Supriya [8] have examined the applicability of ORS Scale in testing the role stress.

\section{Statement of the Problem}

Stress virtually influences every aspect of the life of a person. Organizations, where people spend a major part of their active life, are undoubtedly the potential source of their role stress. Occupational stress has in fact become a predominant feature of modern organizational life and the sources of such stress are manifold. Apart from extra-organizational factors like familial, social, economic

${ }^{*}$ Author for correspondence 
and political, the stressors are mostly organisational, either attached to the role occupied by the individual in the organization or emanating from rest of the organisational structure and climate.

\section{Objective of the Study}

To analyze the organizational role stress, its level and the contributing factors as acquainted by employees working in the IT companies in Bangalore city.

\section{Scope of the Study}

The study covers the employees of select Multinational IT companies in Bangalore and the employees covered were those occupying the role of software engineers and consultants.

\section{Methodology}

\subsection{Sample Size and Sampling Technique}

325 respondents working as software engineers and consultants where chosen. Non-random sampling i.e., convenient sampling method was followed in selecting the sample size. The sample respondents were drawn from select IT companies in Bangalore.

\subsection{Sources of Data}

Primary data was collected by means of a well designed questionnaire. Secondary data was collected from books, journals, etc.

\subsection{Instrumentation}

To analyse the causes of organisational role stress among the employees of select multinational IT companies, the questionnaire administered to respondents to elicit data included 50 items, which covered 10 parameters of organisational role stress. The 10 parameters were divided among 50 questions and each parameter was assigned 5 questions each. The Cronbach Alpha calculated for 50 questions revealed a value of 0.9513 , which denotes its validity.

\subsection{Tools of Analysis}

The statistical tools used for the purpose of this study are simple Percentages, Mean, 'F' test, 't' test, Chi-Square test and Correlation.

\section{Results and Discussion}

\subsection{Profile of the Respondents}

From Table 1, it is evident that $64.61 \%$ were of the age between $21-30$ years, $80 \%$ were male, $96 \%$ were graduates, $72 \%$ were software engineers, $70.15 \%$ had $1-4$ years of experience, $57.53 \%$ were married, $72 \%$ earned annual income between Rs. 3-5 lakhs and 90.77\% hailed from nuclear type family.

\subsection{Analysis of Organisational Role Stress among Employees of Select IT Companies in Bangalore}

The Organisational Role Stress (ORS) scale developed by Pareek [2] was selected for measuring the ten parameters or role stressors (Appendix-I) in the present study, since this exhaustive scale has been already employed in a case study by Bhatt and Pathak [9] and Srivastav [1].

It is evident from Table 2 that the organisational role stress experienced by the respondents through various role stressors is correlated with each other to a highly significant level.

From Table 3 it is clear that majority of the employees of select multinational IT companies in Bangalore experience medium level of organisational role stress. On an average $70.77 \%$ have experienced organisational role stress.

\subsection{Association between Demographic Variables and Organisational Role Stress}

The association between different demographic groups and the role stress was examined by Srivastav [1]. The demographic variables influence the feeling of stress. In the present study, for the purpose of analyzing the association between demographic variables of respondents and the organisational role stress, the following hypothesis was set:

$\mathrm{H}_{\mathrm{o}}$ : Different groups of gender, age, marital status, experience, educational qualification, annual income and type of family do not differ significantly in respect of ORS.

Based on the demographic variables, either ' $t$ ' value or "F" value was calculated.

Table 4 reveals that of the eight demographic variables, experience alone has no significant association with any of the organizational role stressors. The significant association with role stress for the other demographic groups was however diverse and not identical which confirms the findings of Srivastav [1]. 
Table 1. Profile of the respondents

\begin{tabular}{|c|c|c|c|c|}
\hline \multirow{2}{*}{$\begin{array}{l}\text { S.No } \\
1 .\end{array}$} & \multicolumn{2}{|c|}{ Demographic Variables } & \multirow{2}{*}{$\frac{\text { No. of Respondents }}{210}$} & \multirow{2}{*}{$\frac{\text { Percentage }}{64.61}$} \\
\hline & Age (Years) & $21-30$ & & \\
\hline & & $31-40$ & 105 & 32.30 \\
\hline & & Above 40 & 10 & 3.09 \\
\hline \multirow[t]{2}{*}{2.} & Sex & Male & 260 & 80.00 \\
\hline & & Female & 65 & 20.00 \\
\hline \multirow[t]{3}{*}{3.} & Educational & Diploma & 0 & 0 \\
\hline & Qualification & Graduates & 312 & 96.00 \\
\hline & & Post Graduates & 13 & 4.00 \\
\hline \multirow[t]{3}{*}{4.} & Designation & Junior Programmer & 43 & 13.23 \\
\hline & & Software Engineer & 234 & 72.00 \\
\hline & & Senior Software Engineer & 48 & 14.77 \\
\hline \multirow[t]{3}{*}{5.} & Experience & $1-4$ & 228 & 70.15 \\
\hline & (Years) & $4-7$ & 82 & 25.23 \\
\hline & & More than 7 Years & 15 & 4.62 \\
\hline \multirow[t]{2}{*}{6.} & Marital Status & Married & 187 & 57.53 \\
\hline & & Unmarried & 138 & 42.47 \\
\hline \multirow[t]{4}{*}{7.} & Annual Income & Less than 3 Lakhs & 40 & 12.31 \\
\hline & (in Rs.) & 3 - 5 Lakhs & 234 & 72.00 \\
\hline & & 5 - 7 Lakhs & 48 & 14.77 \\
\hline & & More than 7 Lakhs & 3 & 0.92 \\
\hline \multirow[t]{2}{*}{8.} & Family Type & Nuclear & 295 & 90.77 \\
\hline & & Joint & 30 & 9.23 \\
\hline
\end{tabular}

Table 2. Inter-correlation between the role stressors

\begin{tabular}{|c|c|c|c|c|c|c|c|c|c|c|c|}
\hline & & IRD & $\mathrm{RS}$ & REC & $\mathrm{RE}$ & RO & RI & PI & SRD & RA & RIn \\
\hline \multirow[t]{2}{*}{ IRD } & $\mathrm{r}$ & 1 & 0.542 & 0.674 & 0.579 & 0.603 & 0.690 & 0.714 & 0.683 & 0.730 & 0.741 \\
\hline & $\mathrm{p}$ & & $* *$ & $* *$ & $* *$ & $* *$ & $* *$ & $* *$ & $* *$ & $* *$ & $* *$ \\
\hline \multirow[t]{2}{*}{$\mathrm{RS}$} & $\mathrm{r}$ & & 1 & 0.579 & 0.573 & 0.612 & 0.593 & 0.608 & 0.582 & 0.497 & 0.616 \\
\hline & $\mathrm{p}$ & & & $* *$ & $* *$ & $* *$ & $* *$ & $* *$ & $* *$ & $* *$ & $* *$ \\
\hline \multirow[t]{2}{*}{ REC } & $\mathrm{r}$ & & & 1 & 0.727 & 0.781 & 0.752 & 0.781 & 0.731 & 0.697 & 0.701 \\
\hline & $\mathrm{p}$ & & & & $* *$ & $* *$ & $* *$ & $* *$ & $* *$ & $* *$ & $* *$ \\
\hline \multirow[t]{2}{*}{$\mathrm{RE}$} & $\mathrm{r}$ & & & & 1 & 0.770 & 0.640 & 0.755 & 0.699 & 0.495 & 0.783 \\
\hline & $\mathrm{p}$ & & & & & $* *$ & $* *$ & $* *$ & $* *$ & $* *$ & $* *$ \\
\hline \multirow[t]{2}{*}{ RO } & $\mathrm{r}$ & & & & & 1 & 0.708 & 0.772 & 0.675 & 0.606 & 0.774 \\
\hline & $\mathrm{p}$ & & & & & & $* *$ & $* *$ & $* *$ & $* *$ & $* *$ \\
\hline \multirow[t]{2}{*}{ RI } & $\mathrm{r}$ & & & & & & 1 & 0.726 & 0.685 & 0.640 & 0.703 \\
\hline & $\mathrm{p}$ & & & & & & & $* *$ & $* *$ & $* *$ & $* *$ \\
\hline \multirow[t]{2}{*}{ PI } & $\mathrm{r}$ & & & & & & & 1 & 0.766 & 0.631 & 0.765 \\
\hline & $\mathrm{p}$ & & & & & & & & $* *$ & $* *$ & $* *$ \\
\hline \multirow[t]{2}{*}{ SRD } & $\mathrm{r}$ & & & & & & & & 1 & 0.729 & 0.745 \\
\hline & $\mathrm{p}$ & & & & & & & & & $* *$ & $* *$ \\
\hline \multirow[t]{2}{*}{ RA } & $\mathrm{r}$ & & & & & & & & & 1 & 0.672 \\
\hline & $\mathrm{p}$ & & & & & & & & & & $* *$ \\
\hline $\mathrm{R} \ln$ & $\mathrm{r}$ & & & & & & & & & & 1 \\
\hline
\end{tabular}


Table 3. Level of organisational role stress of the respondents

\begin{tabular}{lccccccc}
\hline & \multicolumn{2}{c}{ Low } & \multicolumn{2}{c}{ Medium } & \multicolumn{2}{c}{ High } & Total \\
\cline { 2 - 8 } & $\mathrm{N}$ & $\%$ & $\mathrm{~N}$ & $\%$ & $\mathrm{~N}$ & $\%$ & $\mathrm{~N}$ \\
\hline Inter - role Distance & 55 & 16.92 & 255 & 78.46 & 15 & 4.62 & 325 \\
Role Stagnation & 76 & 23.38 & 223 & 68.62 & 26 & 8.00 & 325 \\
Role Expectation Conflict & 72 & 22.15 & 237 & 72.92 & 16 & 4.92 & 325 \\
Role Erosion & 87 & 26.77 & 208 & 64.00 & 30 & 9.23 & 325 \\
Role Overload & 85 & 26.15 & 214 & 65.85 & 26 & 8.00 & 325 \\
Role Isolation & 84 & 25.85 & 214 & 65.85 & 27 & 8.31 & 325 \\
Personal Inadequacy & 95 & 29.23 & 216 & 66.46 & 14 & 4.31 & 325 \\
Self-Role Distance & 72 & 22.15 & 236 & 72.62 & 17 & 5.23 & 325 \\
Role Ambiguity & 85 & 26.15 & 223 & 68.62 & 17 & 5.23 & 325 \\
Resource Inadequacy & 60 & 18.46 & 247 & 76.00 & 18 & 5.54 & 325 \\
Overall & 78 & 24.00 & 230 & 70.77 & 17 & 5.23 & 325 \\
\hline
\end{tabular}

Table 4. Significance of the influence of the demographic variables of the respondents on the organisational role stress

\begin{tabular}{|c|c|c|c|c|c|c|c|c|c|c|c|}
\hline \multicolumn{2}{|c|}{ Demographic Variables } & \multirow{2}{*}{$\begin{array}{r}\text { IRD } \\
3.40\end{array}$} & \multirow{2}{*}{$\begin{array}{c}\text { RS } \\
2.19\end{array}$} & \multirow{2}{*}{$\begin{array}{c}\text { REC } \\
1.02\end{array}$} & \multirow{2}{*}{$\frac{\mathrm{RE}}{1.09}$} & \multirow{2}{*}{$\begin{array}{c}\text { RO } \\
1.38\end{array}$} & \multirow{2}{*}{$\begin{array}{c}\text { RI } \\
2.87\end{array}$} & \multirow{2}{*}{$\begin{array}{c}\text { PI } \\
2.01\end{array}$} & \multirow{2}{*}{$\begin{array}{c}\text { SRD } \\
3.05\end{array}$} & \multirow{2}{*}{$\begin{array}{c}\text { RA } \\
1.88\end{array}$} & \multirow{2}{*}{$\begin{array}{l}\text { RIn } \\
1.23\end{array}$} \\
\hline Gender & $\mathrm{t}$ & & & & & & & & & & \\
\hline & $\mathrm{p}$ & $0.00 * *$ & $0.03 *$ & 0.31 & 0.28 & 0.17 & $0.00 * *$ & $0.05 *$ & $0.00 * *$ & 0.06 & 0.22 \\
\hline \multirow[t]{2}{*}{ Marital status } & $\mathrm{t}$ & 1.34 & 1.66 & 1.79 & 1.23 & 0.64 & 0.01 & 0.40 & 0.87 & 1.35 & 2.10 \\
\hline & $\mathrm{p}$ & 0.18 & 0.10 & 0.07 & 0.22 & 0.52 & 1.00 & 0.69 & 0.38 & 0.18 & $0.04 *$ \\
\hline \multirow[t]{2}{*}{ Type of family } & $\mathrm{t}$ & 2.23 & 1.26 & 0.46 & 2.00 & 1.89 & 0.43 & 2.14 & 0.03 & 0.08 & 0.36 \\
\hline & $\mathrm{p}$ & $0.03 *$ & 0.21 & 0.65 & $0.05 *$ & 0.06 & 0.67 & $0.03 *$ & 0.98 & 0.93 & 0.72 \\
\hline \multirow[t]{2}{*}{ Age } & $\mathrm{F}$ & 18.62 & 0.37 & 1.49 & 0.88 & 3.19 & 4.25 & 1.65 & 2.57 & 7.54 & 10.26 \\
\hline & $\mathrm{p}$ & $0.00 * *$ & 0.69 & 0.23 & 0.42 & $0.04 *$ & $0.02 *$ & 0.19 & 0.08 & $0.00 * *$ & $0.00 * *$ \\
\hline \multirow[t]{2}{*}{ Experience } & $\mathrm{F}$ & 2.46 & 0.25 & 0.43 & 0.17 & 0.59 & 0.91 & 1.74 & 0.68 & 1.06 & 2.57 \\
\hline & $\mathrm{p}$ & 0.09 & 0.78 & 0.65 & 0.84 & 0.55 & 0.40 & 0.18 & 0.51 & 0.35 & 0.08 \\
\hline \multirow[t]{2}{*}{ Designation } & $\mathrm{F}$ & 2.36 & 1.11 & 0.59 & 1.77 & 0.73 & 0.90 & 0.90 & 1.47 & 1.25 & 1.72 \\
\hline & $\mathrm{p}$ & $0.01 * *$ & 0.35 & 0.85 & $0.05 *$ & 0.72 & 0.55 & 0.54 & 0.13 & 0.25 & 0.06 \\
\hline \multirow{2}{*}{$\begin{array}{l}\text { Highest } \\
\text { Educational } \\
\text { Qualification }\end{array}$} & $\mathrm{F}$ & 8.09 & 0.92 & 0.65 & 3.96 & 1.60 & 1.60 & 3.70 & 2.06 & 2.72 & 4.54 \\
\hline & $\mathrm{p}$ & $0.00 * *$ & 0.40 & 0.52 & $0.02 *$ & 0.20 & 0.20 & $0.03 *$ & 0.13 & 0.07 & $0.01 * *$ \\
\hline \multirow[t]{2}{*}{ Annual Income } & $\mathrm{F}$ & 8.57 & 3.33 & 21.45 & 2.84 & 15.35 & 15.35 & 15.53 & 5.69 & 14.80 & 4.57 \\
\hline & $\mathrm{p}$ & $0.00 * *$ & 0.07 & $0.00 * *$ & 0.09 & $0.00 * *$ & $0.00 * *$ & $0.00 * *$ & $0.02 *$ & $0.00 * *$ & $0.03 *$ \\
\hline
\end{tabular}

** Significant at 0.01 level ; * Significant at 0.05 level

\section{Conclusion}

On analyzing the organizational role stress, its level and the contributing factors as acquainted by employees working in the select IT companies in Bangalore city, the study has divulged the fact that the role stress acquainted by the employees is not identical but diverse, which affirms the findings of Srivastav [1]. Hence a better identification of the diverse problems persistent with the employees in the discharge of their job obligations can be resolved with right and effective measures.

\section{References}

1. Srivastav A.K., Heterogeneity of role stress, research and practice in human resource management, vol. 18(1), pp. 16-27, 2010. Available: www.rphrm.curtin.edu.au

2. Pareek U., Organisational role stress, L.D. Goodstein, J.W. Pfeiffer (Eds.), The 1983 Annual, San Diego, CA: University Associates, pp. 115-123, 1983.

3. Beehr T.A., Work-role stress and attitude towards co-workers - group and organisation management, vol. 6(2) pp. 201-210, 1981, DOI: 10.1177/105960118100600206. 
4. Ahmed S., Bharadwaj A., Narula S., "A study of stress among executives", J Pers Clin Stud, vol. 1(2), pp. 47-50, 1985.

5. Pestonjee, D.M., A study of role stresses in top and middle management, 1988 May, WP1988-05-01-00825. Available: ideas.repec.org/p/iim/iimawp/wp00825.html

6. Satyanarayana K., "Stressors among executives and supervisors: a comparative study in a public sector undertaking", Osmania Journal of Psychology., vol. 19(2), pp. 1-9, 1995.

7. Lehal R., Singh S., "Organisational role stress among college teachers of Patiala District: a comparative study of government and private colleges", RIMT Journal of Strategic Management and Information Technology., vol. 2(1,2), pp. 24-30, 2005 Jan-Jun.

8. Yasmeen H., Supriya M.V, "Organisational role stress: confirmatory factor analysis approach", Asia-Pacific Journal of Management Research and Innovation, Asia-Pacific Business review, vol. 4(2), pp. 29-33, 2008 Apr-Jun.

9. Bhatt S., Pathak P., "Occupational stress among IT/ITES professionals in leading Metros in India: a case study",
Asia-Pacific Journal of Management Research and Innovation, Asia-Pacific Business Review, vol. 6(3), pp. 165-177, 2010 JulSep.

\section{Appendix-I}

Ten parameters/role stressors (Pareek) [2]

*Inter role distance (IRD)

*Role stagnation (RS)

*Role expectation conflict (REC)

$*$ Role erosion (RE)

*Role overload (RO)

*Role isolation (RI)

*Personal inadequacy (PI)

*Self role distance $(\mathrm{SRD})$

$*$ Role ambiguity (RA)

*Resource inadequacy (RIn) 